\title{
A SIDELIGHT ON THE LIQUOR TRAFFIC THREE HUNDRED YEARS AGO.
}

\author{
BY F. J. C. HEARNSHAW, M.A., LL.M., \\ Professor of History and Economics, Hartley University College, \\ Southampton.
}

ThE borough of Southampton is rich in historical documents, which cover with varying degrees of fulness the whole period from the time of King John down to the present day. Among the documents by no means the least interesting is the long series of the records of the Court Leet, a court of immemorial antiquity and once of great importance, which even yet survives, though it has lost all its ancient power and glory.

This court, which met, and still meets, once a year only, three weeks after Easter, had charge in the old days of the interests of the community as a whole. It safeguarded the common rights, saw to the maintenance of the highways and byways, looked after the defence of the borough and the keeping of watch and ward, regulated trade and industry, and gave attention to the health and morals of the burgesses. Under these latter headings the liquor traffic came in for frequent and particular notice at the hands of the Court Leet jurors, who year by year made presentments of the evils and abuses which they found current in the town.

The following selected entries from the records of the years A.D. 1550-1602 (which have recently been edited and published by the Southampton Record Society), will serve to show the kind of problems which faced the municipal administrators of three hundred years ago. 


\section{The British Journal of Inebriety}

\section{PREVALENCE OF DRUNKENNESS.}

Drunkenness seems to have been in all ages one of the easily. besetting sins of Englishmen. The national drink in the time of Queen Elizabeth was beer, though the upper classes had the light wines of France or the Levant, and the dwellers in the orchard counties cider or perry. Probably few, except under stress of extreme poverty or urgent necessity, drank water; to do so was too dangerous. In Southampton, for example, the watersupply came fitfully and scantily and uncertainly from two or three conduit-heads half a mile to a mile distant from the town. It was conveyed through wooden pipes, which not only allowed much water to leak out, but also permitted much drainage to filter in. The conditions of life were in the highest degree insanitary, and water must have been a frequent vehicle of disease. Water, moreover, was (and is) a somewhat flat and uninteresting beverage; therefore, since tea and other cheering but not inebriating drinks were unknown, men turned to assuage their thirst and fill up the monotonous wastes of their leisure with beer. A little money went a long way. We are told, for example, of two men who drank together for six hours in an inn at a total cost of fourpence. At the end of their debauch they went out and fought with swords till one slew the other.

The abuse of excessive drinking was so great that the Leet jurors say: "Item wee present the notorious sinne of dronkennes to be so Comon in this Towne as except some spedye reformacon be taken thereof in your discrecions yt will redowne to the great infamye of the publicke government." They complain also of the excessive number of alehouses thus: "Item we present the inordinate and unnecessarie number of Alehowse keepers within everie warde of this towne being receptakles of all lewd persons and authors and maynteynors of them in there vices and wickednes," and they pray that some of them may be suppressed. The jurors further make strong representations concerning the persons who haunt taverns and spend their time in drinking and gamb-

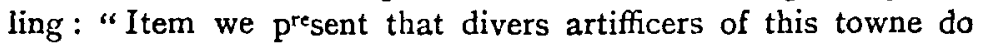
now usse to haunt taverns and alehouses not only by day but also by night so that many of them spend more than they get "; and they ask that every alehouse-keeper who has any artificer on his premises after 9 p.m. shall be fined 5 s., and that everyone who allows gambling in his house shall be subject to a penalty 
of 4os. In order to facilitate the enforcement of these and similar regulations, they suggest that all the back-doors of the taverns leading into the fields shall be closed up, so that there shall be but one way of ingress and egress.

\section{LICENSES.}

All those who "tippled"-that is, who sold beer retail-were expected to secure licenses, the usual cost of which seems to have been Is. a year. It appears, however, to have been very difficult to enforce this regulation, for year after year persons are presented for selling beer without a license. Thus in 1571: "Item we do presente that Edward deboke, Clerk's widdowe, John Cavell, Ester hamon, nicholas sendall, and James permitte dothe tipple and ar nott bounde in recognizans wherfor every of them ar to losse 20s." Under similar circumstances in 1580 one Robert Vaughan is fined 20s. and is imprisoned for three days, and is required "befor his coming out to put in surtis not to keepe any victual. ling howse without lyssens."

\section{TESTING AND SEALING OF MEASURES.}

Another matter which caused a great deal of trouble was the maintenance of a uniform standard of measures. Every year the Leet jurors went the round of the inns and taverns and examined the measures. Their inquisitorial visits seem to have excited keen resentment. For example, in 1577 they say: "Item we present that at $J$ o erryngtons we could fynde no wyne potts unsealid, not with $^{\text {th }}$ tanding we thincke theye were ther (as also in thother taverns) many conveyed out of our sightes, and when we came thither we had evill language geven us by Mrs eryngton." The use of stone pots was prohibited, because they could not be sealed in the manner required. In 157 I no less than thirty-one innholders were either warned against selling by stone pots or were fined for having done so. In 1576 the general rule was laid down in these words: "Be yt commandid unto all the vinteners and taverners within this towne and county of Southampton from hencefoorthe not to sell eny wynes by any other mesures than by suche as are sealid and gadged by the auntient standers of this towne uppon payne off forfeightinge for every such pott so founde greate or small in eny of there houses the offen- 
dors theirein to pay $£$ ro wheareof the one halffe to be to the taker and the other halffe to the usse of the towne." There is no evidence, however, that this very heavy penalty was enforced or that the evil abated.

THE SIZE OF BEER-BARRELS.

Not only the capacity and material of measures in the hands of the "tipplers," but also the size of the barrels in which the brewers distributed their popular beverage, came in for regula. tion. Thus: "Item we present that Robert Russell doth use to sell his beere in barrells callid humber barrells wch ought to contayne two kilderkins [i.e., 36 gallons] w $w^{\text {ch }}$ humber barrells doth want three gallons at the least to the great decept of the Quens majesty's subjects and especially the poore of this towne." Hence Robert Russell is fined $£$ Io and threatened with a fine of $£ 40$ if he offends again. Not only the brewers, however, were liable on the score of deceptive barrels; the coopers who made the barrels also came in for their share of invigilation and rebuke. The coopers were bound to take every barrel made in their yards to the town sergeant to have it tested by the town's " auntient gadge or standard of iron," and then they had to issue it sealed with the town seal and marked with the cooper's own distinctive mark. They frequently failed to obey this wholesome regulation-the difficulty of securing obedience to law is one of the keys to the history of Early English institutions-and the jurors appeal for its more rigorous enforcement. But even when the coopers made honest barrels and the brewers bought them, there was another trick which enabled these same crafty brewers to reap dishonourable gain. They did not fill them full, and in order to conceal the deficiency they took them jolting journeys along the ill-paved roads, until the shaking and "spurging" created a foam and froth within the barrels which obliterated completely the boundary-line twixt liquid and air. The jurors would not tolerate such guile. They ordered filling beer to be taken round, and all deficiencies to be made good. These are their righteously indignant words: "We present that the brewers do not bring fillinge beere to fill ther barrells accordinge to the aunciant costom, wherfor we desire that they may have a kyttell with a pype and bere with them to fille the same for that yt is a great robbing of the poore and ryche, and great exclamation therof groweth by 
the poor. Be yt comaundid to them to bring filling bere and fill ther vessalls uppon payne of $E$ ro a pece, for they gayneth much more therbye."

\section{QUALITY AND PRICE OF BEER.}

In Elizabethan England practically every process of industry and commerce was subject to regulation either by the central or the local authority. The weight of bread, the width of cloth, the size of bricks, the hours of labour, the number of labourers, the qualities and prices of everything, were fixed and determined. As to beer, the tendency of the brewers was to make it too strong. The jurors complained that the weak and comparatively innocuous "small beer" was not easy to obtain; the brewers preferred to brew, contrary to order, a pungent and heady "double beer," for which, no doubt, they found a much rore steady demand and ready sale. In I 594 a fine of $£$ Io each was imposed upon seven brewers "for not brewing of good and bolesome small beere according as it was given them in order," for as the result of their disobedience the townsmen were "dryven to buye their drinck at alhowses to their prejudice." On another occasion twelve brewers were mulcted $6 \mathrm{~s}$. $8 \mathrm{~d}$. each for selling "double beere contrarie to order and commandment."

As to the price of beer three hundred years ago, it seems to us ridiculously low, but we have to recollect that money at that time had on the average at least ten times the purchasing power which it has now. In 1575 an entry was made as follows: "Item we present that whereas the pryse of maulte is fawllen yet notwithstanding the brewers kepyth the pryse of bere at $2 \mathrm{~s}$. the barrell which is excessive considering the pryse of maulte and hopps, wherof we pray redres."

\section{MISCELLANEOUS REGULATIONS.}

Many minor matters connected directly or indirectly with the liquor traffic came up for consideration from time to time. For example, the brewers persisted in using "iron-bound" cartsthat is to say, carts whose wheels were encircled with a band or rim of iron. Complaints were made by the householders (who, each in front of his own dwelling, had to keep the roads in repair) that the streets of the town were ruined by the passage of these 
lumbering wains. Hence fines were levied on the brewers to compensate for the destruction they caused.

Another matter that gave trouble was the use of clay by the brewers to stop the bungholes of their barrels. They digged their clay on the common lands of the town, and they left great holes in the ground, into which cattle fell, and which seriously interfered with the practice of archery. They, therefore, were forbidden to dig clay on the common lands, and the porters of the town were ordered to fill up the holes with the town's refuse. So far as one can gather from the records, neither brewers nor porters took any notice of these instructions.

A third minor problem arose from the great consumption of wood in the furnaces of the brewers. The whole stock' of fuel brought in from the forest to Southampton tended to pass into the hands of these insatiable monopolists, to the serious enbancing of the price to the commonalty. Hence it was "comaundid that no brewers of this towne nether within the walls nor without doo buye eny wood that usseth to come to this towne by carte, but shall make ther provission by water "-that is, shall import their wood from more distant regions, so that the home supply shall not be interfered with.

The entries, as a whole, give us an interesting glimpse of one aspect of English town life in a bygone age. The problems of that day are not our problems to-day. It has been given to us to see life under new conditions and in new lights, and in particular to view the liquor traffic and the temperance question from a wholly different point of view from that which our ancestors assumed. 